\title{
Probably less than one-tenth of the genes produce only the wild type protein without at least one additional protein isoform in some human cancer cell lines
}

\author{
Rui Yan', Ju Zhang ${ }^{2}$, Lucas Zellmer ${ }^{3}$, Lichan Chen ${ }^{3}$, Di Wu ${ }^{4}$, Siqi Liu², Ningzhi Xu ${ }^{5}$ \\ and Joshua D. Liao ${ }^{6}$ \\ ${ }^{1}$ Nephrology Department, Guizhou Medical University Hospital, Guiyang, P.R. China \\ ${ }^{2}$ CAS Key Laboratory of Genome Sciences and Information, Beijing Institute of Genomics, Chinese Academy of Sciences, \\ Beijing, P.R. China \\ ${ }^{3}$ Hormel Institute, University of Minnesota, Austin, Minnesota, USA \\ ${ }^{4}$ Beijing Protein Innovation Co., Ltd, Beijing, P.R. China \\ ${ }^{5}$ Laboratory of Cell and Molecular Biology \& State Key Laboratory of Molecular Oncology, National Cancer Center/Cancer \\ Hospital, Chinese Academy of Medical Sciences \& Peking Union Medical College, Beijing, P.R. China \\ ${ }^{6}$ Department of Pathology, Guizhou Medical University Hospital, Guiyang, P.R. China \\ Correspondence to: Rui Yan, email: yanrui@gmc.edu.cn \\ Siqi Liu, email: siqiliu@genomics.cn \\ Ningzhi Xu, email: xuningzhi@cicams.ac.cn \\ Joshua D. Liao, email: djliao@gmc.edu.cn \\ Keywords: proteomics, mass spectrometry, protein isoform, western blotting, immunohistochemical staining \\ Received: March 14, $2017 \quad$ Accepted: June 30, $2017 \quad$ Published: August 07, 2017 \\ Copyright: Yan et al. This is an open-access article distributed under the terms of the Creative Commons Attribution License 3.0 \\ (CC BY 3.0), which permits unrestricted use, distribution, and reproduction in any medium, provided the original author and source \\ are credited.
}

\section{ABSTRACT}

To estimate how many genes produce multiple protein isoforms, we electrophoresed proteins from MCF7 and MDA-MB231 (MB231) human breast cancer cells in SDS-PAGE and excised narrow stripes of the gel at the 48kD, 55kD and $72 \mathrm{kD}$. Proteins in these stripes were identified using liquid chromatography and tandem mass spectrometry. A total of 765, 750 and 679 proteins from MB231 cells, as well as 470, 390 and 490 proteins from MCF7 cells, were identified from the $48 \mathrm{kD}, 55 \mathrm{kD}$ and $72 \mathrm{kD}$ stripes, respectively. We arbitrarily allowed a $10 \%$ technical variation from the proteins' theoretical molecular mass (TMM) and considered those proteins with their TMMs within the 43-53 kD, 49-61 kD and 65-79 kD ranges as the wild type (WT) expected from the corresponding stripe, whereas those with a TMM above or below this range as a smaller- or larger-group, respectively. Only $263(34.4 \%), 269$ (35.9\%) and $151(22.2 \%)$ proteins from MB231 cells and $117(24.9 \%), 135(34.6 \%)$ and 130 (26.5\%) proteins from MCF7 cells from the 48kD, 55kD and $72 \mathrm{kD}$ stripes, respectively, belonged to the WT, while the remaining majority belonged to the smaller- or largergroups. Only about 3-16\%, on average about $10 \%$ regardless of the stripe and cell line, of the proteins appeared in only one stripe and within the WT range, while the remaining preponderance appeared also in additional stripe(s) or had a larger or smaller TMM. We conclude that few (fewer than $10 \%$ ) of the human genes produce only the WT protein without additional isoform(s). 


\section{INTRODUCTION}

A large number of genes in the human genome undergo alternative initiation or termination of transcription to generate different RNA transcripts. Over $95 \%$ of the human genes contain exons and introns, and $95 \%$ of these genes undergo alternative splicing to generate different mRNAs [1]. One mRNA may also be expressed to different protein isoforms via various mechanisms such as use of an alternative start codon or stop codon, as we recently reviewed [2]. Because of these and other mechanisms, in most cases one gene often produces multiple protein isoforms [3, 4], which provides the gene with multiple ways to diversify its functions and in turn allows the cell to be more flexible adapting to the environment. However, a good estimation on how many genes in the human genome produce multiple protein isoforms is still lacking, mainly due to the lack of convenient but reliable technology, although there have been frequent attempts [5].

Liquid chromatography together with tandem mass spectrometry, or LC-MS/MS, is a common approach for protein identification in a high throughput manner and has resulted in a huge amount of data [6-8], which should facilitate annotating protein-coding genes to a large extent [9] and have clinical value [10]. Routine LC-MS/ MS is conducted in a bottom-up manner [11], in which intact proteins within the SDS-containing polyacrylamide gel (SDS-PAGE) are digested with a protease into short peptides, whereupon the short peptides are identified using LC-MS/MS in combination with a match of the MS data to a peptide reference. In an earlier study, we excised a narrowstripe of SDS-PAGE at $26 \mathrm{kD}$ or $40 \mathrm{kD}$ for LCMS/MS analysis [12]. To our surprise, results from this sort of top-down approach of LC-MS/MS showed that only one-third to one-fourth of the proteins migrated in SDS-PAGE as anticipated from their theoretical molecular mass (TMM), while the vast rest of the proteins were those with a larger or a smaller TMM. Moreover, many proteins appeared in both of the $26 \mathrm{kD}$ and $40 \mathrm{kD}$ stripes, including some having a much larger or smaller TMM than $26 \mathrm{kD}$ or $40 \mathrm{kD}$, indicating that these genes have one or more additional isoforms besides the wild type (WT) protein, i.e. the protein with its TMM expected in the $26 \mathrm{kD}$ or $40 \mathrm{kD}$ stripe [12].

Western blotting (WB) is a common method for protein identification and semi-quantification, involving fractionation of proteins through SDS-PAGE, transfer of the proteins from the gel onto a membrane, and identification of the protein in question as a band on the membrane using a specific antibody [3]. As already explained in detail previously [12], proteins are known to be subject to many different types of chemical modification after synthesized in the ribosomes, including phosphorylation, de-phosphorylation, glycosylation, SUMOylation, ubiqulation, proteolysis, etc. More complexly, some of these modifications, such as phosphorylation, can occur at many sites of a single protein. Because of these complex post-translational modifications, together with the aforementioned relations at the transcriptional, posttranscriptional and translational levels, most genes will likely produces multiple bands in WB, in a large part because of multiple protein isoforms. However, ignoring this fact, most published studies reporting WB data present only one single band on the membrane, which implies to the readers that the gene produces only one single form of protein, with attribution of all observed functions of the gene to this one form of protein without discussing the possible contribution of other sibling proteins $[4,12]$.

In the present study, we continued to use our simplified top-down approach to analyze proteins isolated from SDS-PAGE at larger $(48 \mathrm{kD}, 55 \mathrm{kD}$ and $72 \mathrm{kD})$ molecular weights. The resulting data not only dovetail with our previous findings at lower ranges of SDS-PAGE but also further suggest that few genes in the human genome produce only the WT protein without at least one additional isoform.

\section{RESULTS}

\section{The rates of peptide spectra matched to the reference were low}

LC-MS/MS identified 43462-57078 spectra as clear inputs from different gel stripes of the two cell lines (Table 1). However, only $11.74-21.13 \%$ of these clear inputs could be matched to the reference and led to identification of proteins, whereas the remaining inputs were unmatchable. Adjustment of the cutoff parameters could modify the ratios of the matched to the unmatchable but could not change the fact that most inputs were unmatchable.

\section{In SDS-PAGE, most proteins did not migrate as expected from their TMMs}

LC-MS/MS identified 765, 750 and 679 proteins from MB231 cells, as well as 470, 390 and 490 proteins from MCF7 cells, from the $48 \mathrm{kD}, 55 \mathrm{kD}$ and $72 \mathrm{kD}$ stripes, respectively (Table 2; Supplementary Data 1). We arbitrarily set a $10 \%$ divergence at the left or the right side of the TMM as the allowed variation, which is a lax criterion allowing those proteins with a TMM within the $43-53 \mathrm{kD}, 49-61 \mathrm{kD}$ and $65-79 \mathrm{kD}$ ranges to be the WT, or the expected, in the $48 \mathrm{kD}, 55 \mathrm{kD}$ and $72 \mathrm{kD}$ stripes, respectively. As we described before [12], those proteins with their TMMs above or below these ranges were categorized into a smaller-group or a larger-group, respectively, because their positions in the gel were smaller or larger, respectively, than their TMMs (Table 2).

There only were 263/765 (34.4\%), 269/750 (35.9\%) and $151 / 679(22.2 \%)$ proteins identified from the $48 \mathrm{kD}$, $55 \mathrm{kD}$ and $72 \mathrm{kD}$ stripes, respectively, from MB231 
Table 1: The rates of the inputs matched to the reference

\begin{tabular}{|c|c|c|c|c|c|c|}
\hline \multirow[t]{2}{*}{ Stripe } & \multicolumn{3}{|c|}{ MB231 } & \multicolumn{3}{|c|}{ MCF7 } \\
\hline & Search input & PSMs & Match rate & Search input & PSMs & $\begin{array}{l}\text { Match } \\
\text { rate }\end{array}$ \\
\hline $72 \mathrm{kDa}$ & 51414 & 9416 & $18.31 \%$ & 45504 & 7624 & $16.75 \%$ \\
\hline $55 \mathrm{kDa}$ & 53899 & 11345 & $21.05 \%$ & 48052 & 5640 & $11.74 \%$ \\
\hline $48 \mathrm{kDa}$ & 57078 & 12063 & $21.13 \%$ & 43462 & 7228 & $16.63 \%$ \\
\hline
\end{tabular}

PSMs: peptide spectrum matches.

Table 2: Fraction of LC-MS/MS identified proteins by their TMMs

\begin{tabular}{|c|c|c|c|c|c|c|}
\hline \multirow{2}{*}{$\begin{array}{l}\text { Cell } \\
\text { line }\end{array}$} & \multicolumn{2}{|c|}{ 48kD stripe } & \multicolumn{2}{|c|}{ 55kD stripe } & \multicolumn{2}{|c|}{$72 \mathrm{kD}$ stripe } \\
\hline & TMM (kD) & $\begin{array}{c}\text { Number of } \\
\text { proteins }\end{array}$ & TMM (kD) & $\begin{array}{c}\text { Number of } \\
\text { proteins }\end{array}$ & TMM (kD) & $\begin{array}{c}\text { Number of } \\
\text { proteins }\end{array}$ \\
\hline \multirow{4}{*}{ MB231 } & $>53$ (smaller) & $178(23.3 \%)^{a}$ & $>61$ (smaller) & $117(15.6 \%)^{a}$ & $>79$ (smaller) & $89(13.1 \%)^{a}$ \\
\hline & 43-53 (WT) & $263(34.4 \%)$ & 49-61 (WT) & $269(35.9 \%)$ & 65-79 (WT) & $151(22.2 \%)$ \\
\hline & <43 (larger) & $324(42.4 \%)^{a}$ & <49 (larger) & $364(48.5 \%)^{a}$ & $<65$ (larger) & $439(64.7 \%)^{a}$ \\
\hline & Total & $765(100 \%)$ & Total & $750(100 \%)$ & Total & $679(100 \%)$ \\
\hline \multirow{4}{*}{ MCF7 } & $>53$ (smaller) & $274(58.3 \%)$ & $>61$ (smaller) & $189(48.5 \%)$ & $>79$ (smaller) & $134(27.3 \%)$ \\
\hline & 43-53 (WT) & $117(24.9 \%)$ & 49-61 (WT) & $135(34.6 \%)$ & 65-79 (WT) & $130(26.5 \%)$ \\
\hline & <43 (larger) & $79(16.8 \%)$ & <49 (larger) & $66(16.9 \%)$ & <65 (larger) & $226(46.1 \%)$ \\
\hline & Total & $470(100 \%)$ & Total & $390(100 \%)$ & Total & $490(100 \%)$ \\
\hline
\end{tabular}

$a$ : significantly different from its counterpart from MCF7 cells ( $\mathrm{p}<0.01 ; \chi^{2}$ test).

cells with their TMMs within the WT ranges, while the remaining $502(65.5 \%), 481$ (64.1\%), and $528(77.8 \%)$ proteins, respectively, belonged to either the larger-group or the smaller-group (Table 2). Similarly, there only were $117 / 470(24.9 \%), 135 / 390(34.6 \%)$ and 130/490 (26.5\%) proteins identified from the $48 \mathrm{kD}, 55 \mathrm{kD}$ and $72 \mathrm{kD}$ stripes, respectively, from MCF7 cells with their TMMs within the WT ranges, while the remaining 353 (75.1\%), 255 $(65.4 \%)$ and $360(73.5 \%)$ proteins, respectively, belonged to either the larger-group or the smaller-group (Table 2).

The larger-group and smaller-group showed significant differences between the two cell lines: MCF7 cells had $58.3 \%, 48.5 \%$ and $27.3 \%$ of the total proteins identified from the $48 \mathrm{kD}, 55 \mathrm{kD}$ and $72 \mathrm{kD}$ stripes, respectively, with their TMMs larger than the WT ranges, percentages which were significantly higher than their counterparts from MB231 cells that were 23.3\%, 15.6\% and $13.1 \%$, respectively (Table 2). Reciprocally, MCF7 cells had $16.8 \%, 16.9 \%$ and $46.1 \%$ of the total proteins from the $48 \mathrm{kD}, 55 \mathrm{kD}$ and $72 \mathrm{kD}$, respectively, with their TMMs below the WT ranges, significantly lower than their counterparts from MB231 cells that were 42.4\%, $48.5 \%$ and $64.7 \%$, respectively (Table 2 ). We plotted the number of the proteins from each stripe according to their TMMs, and the resulting distribution curve from MCF7 cells showed a higher right tail but a lower left tail, compared with the curve from MB231 cells (Figure 1), which dovetailed with the above described difference in the percentages of the larger- and smaller-groups between the two cell lines.

\section{A smaller coverage rate might indicate that a protein lacks part(s) of the sequence}

A total of 1435 and 906 proteins from all three stripes from MB231 and MCF7 cells, respectively, contained two or more unique LC-MS/MS-identified peptides and thus had a definite identity. For each of these proteins we calculated its coverage rate (CR) of identified peptides (Table 3 and Figure 2 ), i.e. the total amino acids (AAs) of all identified peptides as the percentage of the total AAs of the WT protein [12]. The averages of the CRs of the 1435 and 906 proteins were $17.96 \%$ and $15.94 \%$, respectively. The averages of the CRs of the WT proteins, i.e. those proteins with a TMM within the WT range, were $21.21 \%$ and $19.27 \%$ from MB231 and MCF7 cells, respectively, significantly higher than the $10.40 \%$ and $14.11 \%$ averages of the CRs of the proteins in the smaller-group, i.e. those with a TMM above the WT 
Table 3: Average of coverage rate (ACR) and CR $>\mathbf{2 0 \%}$ of different protein groups

\begin{tabular}{|c|c|c|c|c|c|c|c|c|}
\hline \multirow{2}{*}{$\begin{array}{l}\text { Cell line } \\
\text { Group }\end{array}$} & \multicolumn{4}{|c|}{ MB231 } & \multicolumn{4}{|c|}{ MCF7 } \\
\hline & Total & Smaller & WT & Larger & Total & Smaller & WT & Larger \\
\hline ACR & $17.96 \%$ & $10.40 \%$ & $21.21 \% *$ & $17.95 \%$ & $15.94 \%$ & $12.67 \%$ & $19.27 \% *$ & $18.20 \%$ \\
\hline $\mathrm{CR}>20 \%$ & $32.82 \%$ & $12.22 \%$ & $40.04 \% *$ & $33.91 \%$ & $27.48 \%$ & $18.74 \%$ & $38.11 \% *$ & $31.46 \%$ \\
\hline
\end{tabular}

*: Significantly higher than the smaller-group ( $\mathrm{p}<0.05$, Wilcoxon rank sum test due to large variation).

ranges, from MB231 and MCF7 cells, respectively. Actually, $40.43 \%$ and $38.11 \%$ of the WT proteins from MB231 and MCF7 cells, respectively, had a CR $>20 \%$, higher than the CRs of $12.22 \%$ and $18.74 \%$ of the proteins with a TMM above the WT range. In general, proteins with smaller TMMs had a higher CR than proteins with larger TMMs (Figure 1), as we reported previously [12].

For a given protein, the LC-MS/MS-identified peptides should be randomly distributed across the protein. Therefore, the "approximate coverage of truncated proteins" (ACTP), calculated as the coverage of the predicted truncated proteins with its first and last identified AAs as the $\mathrm{N}$ - and $\mathrm{C}$-terminators, has been adopted to analyze the dispersion of the identified peptides across the protein and further estimate the distribution of those isoforms smaller than the WT form [12]. The results showed that compared with CR, ACTP of the smaller isoforms was much closer to that of the WT protein (Figure 2), countenancing the conclusion that there might be many smaller isoforms with an N- or C-terminal truncation. However, neither CR nor ACTP could distinguish those proteins larger than their TMMs from the WT proteins. Moreover, since ACTP could not mask the effect of the alternative splicing of the exons encoding the middle region of the protein, ACTP distribution of those proteins with smaller TMMs could not coincide with that of the WT proteins.

\section{One-tenth of the proteins meet two criteria, i.e. within the WT range and solely in one stripe}

Of the 470, 390 and 490 proteins identified from the $48 \mathrm{kD}, 55 \mathrm{kD}$ and $72 \mathrm{kD}$ stripes, respectively, from MCF7 cells, only $183(38.9 \%), 50$ (12.8\%) and 173 (35.3\%) appeared solely in the stripe, coined herein as "unique proteins" (Table 4), while the remaining 287 (61.1\%), 340 $(87.2 \%)$ and $317(64.7 \%)$ proteins, respectively, appeared in one or two additional stripes. Of these 183, 50 and 173 unique proteins, only 42, 11 and 54, respectively, had their TMMs within the WT ranges, which constituted $23.0 \%$, $22.0 \%$ and $31.2 \%$, respectively, of the unique proteins but only $8.9 \%, 2.8 \%$ and $11.0 \%$ of the total proteins identified from the corresponding stripe (Table 5). The remaining 141 (77.0\% of the unique but $30.0 \%$ of the total), $39(78.0 \%$ of the unique but $10.0 \%$ of the total) and $119(68.8 \%$ of the unique but $24.3 \%$ of the total) proteins had their TMMs out of the WT ranges and thus might have their WT protein at another position of the gel, if the WT one was expressed.

Similarly, of the 765, 750 and 679 proteins identified from the $48 \mathrm{kD}, 55 \mathrm{kD}$ and $72 \mathrm{kD}$ stripes, respectively, from MB231 cells, only 223 (29.2\%), 134 (17.9\%), and 260 $(38.3 \%)$ appeared solely in the stripe (Table 4), while the remaining $542(70.8 \%), 616(82.1 \%)$, and $419(61.7 \%)$ proteins, respectively, were also detected in one or two additional stripes. Of these 223, 134 and 260 unique proteins, only 85, 76 and 108, respectively, had their TMMs within the WT ranges, which constituted 38.1\%, 56.7\% and $41.5 \%$, respectively, of the unique proteins but only $11.1 \%, 10.1 \%$ and $15.9 \%$ of the total proteins identified in the corresponding stripe (Table 5). The remaining 138 (61.9\% of the unique but $18.0 \%$ of the total), $58(43.3 \%$ of the unique but $7.7 \%$ of the total) and $152(58.5 \%$ of the unique but $22.4 \%$ of the total) proteins had their TMMs out of the WT ranges and thus might have their WT protein somewhere else in the gel, if the WT one was expressed.

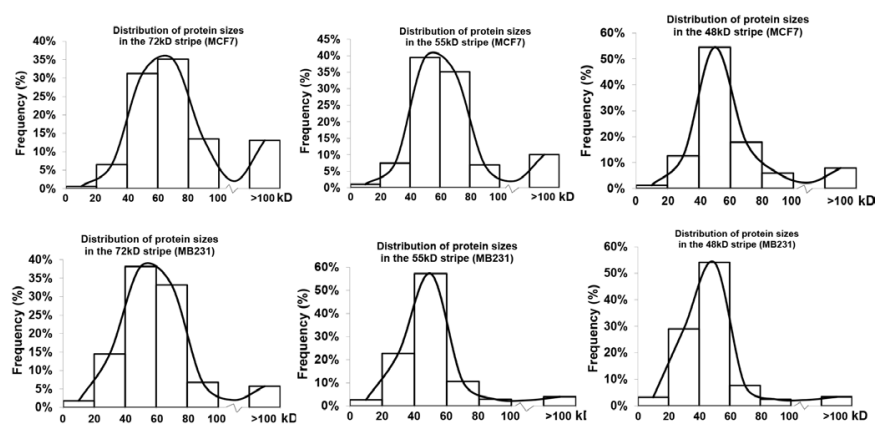

Figure 1: Distribution of proteins identified from each stripe from each cell line according to their TMMs. Note that the three distribution curves from MCF7 cells have a higher right tail but a lower left tail compared with the curve from MB231 cells. 
Table 4: Number of proteins identified in one or more stripes

\begin{tabular}{|c|c|c|c|c|c|}
\hline \multirow{2}{*}{$\frac{\text { Stripe(s) }}{48 \mathrm{kD} \text { only }}$} & \multicolumn{2}{|c|}{ MCF7 } & \multicolumn{3}{|c|}{ MB231 } \\
\hline & $183(23.5 \%)$ & & 224 & $17.7 \%$ & \\
\hline $55 \mathrm{kD}$ only & $52(6.7 \%)$ & $407(52.2 \%)$ & 134 & $10.6 \%$ & $619(49.0 \%)$ \\
\hline $72 \mathrm{kD}$ only & $172(22.1 \%)$ & & 261 & $20.7 \%$ & \\
\hline $48-\& 55-\mathrm{kD}$ & $60(7.7 \%)$ & & 226 & $17.9 \%$ & \\
\hline $48-\& 72-\mathrm{kD}$ & $35(4.5 \%)$ & $181(23.2 \%)$ & 28 & $2.2 \%$ & $357(28.3 \%)$ \\
\hline 55- \& 72-kD & $86(11.0 \%)$ & & 103 & $8.2 \%$ & \\
\hline $\begin{array}{l}48-\& 55-\& \\
72-k D\end{array}$ & 192 & $24.6 \%$ & 287 & & $22.7 \%$ \\
\hline Total Proteins & 780 & $100.0 \%$ & 1263 & & $100.0 \%$ \\
\hline
\end{tabular}

On average, only $28.1 \%$ (from MB231) and $30.1 \%$ (from MCF7) of the proteins from all three stripes were detected solely in a single stripe, regardless whether they migrated as expected from their TMMs, with the remaining $71.9 \%$ (from MCF7) and $69.9 \%$ (from MB231) of the proteins appeared in at least one additional stripe (Table 5). If only those unique proteins
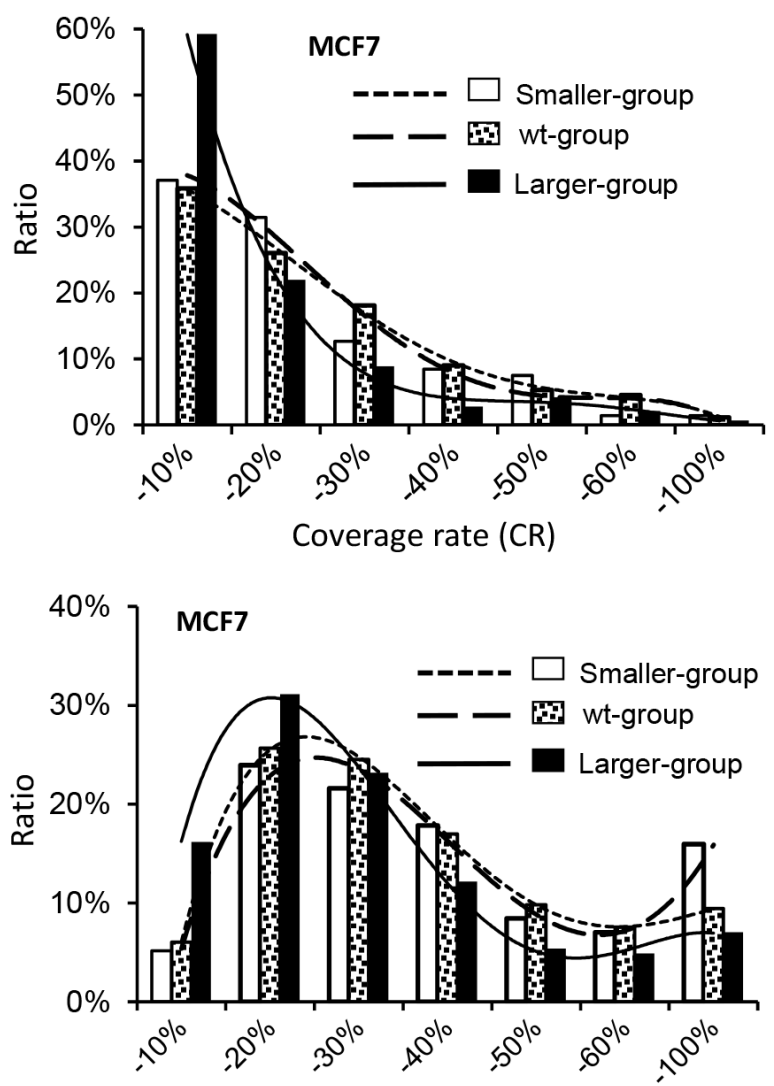

Approximate coverage of truncated protein (ACTP) that were within the WT range were counted, the percentage declined to $7.9 \%$ for MCF 7 cells and $12.3 \%$ for MB231 cells (Table 4), and averaging both cell lines, i.e. the $7.9 \%$ and $12.3 \%$, got $10.1 \%$, or about one-tenth. On the other hand, $24.6 \%$ (from MCF7) and $22.7 \%$ (from MB231) of the proteins identified by LC-MS/MS appeared in all three stripes (Table 4), and averaging both
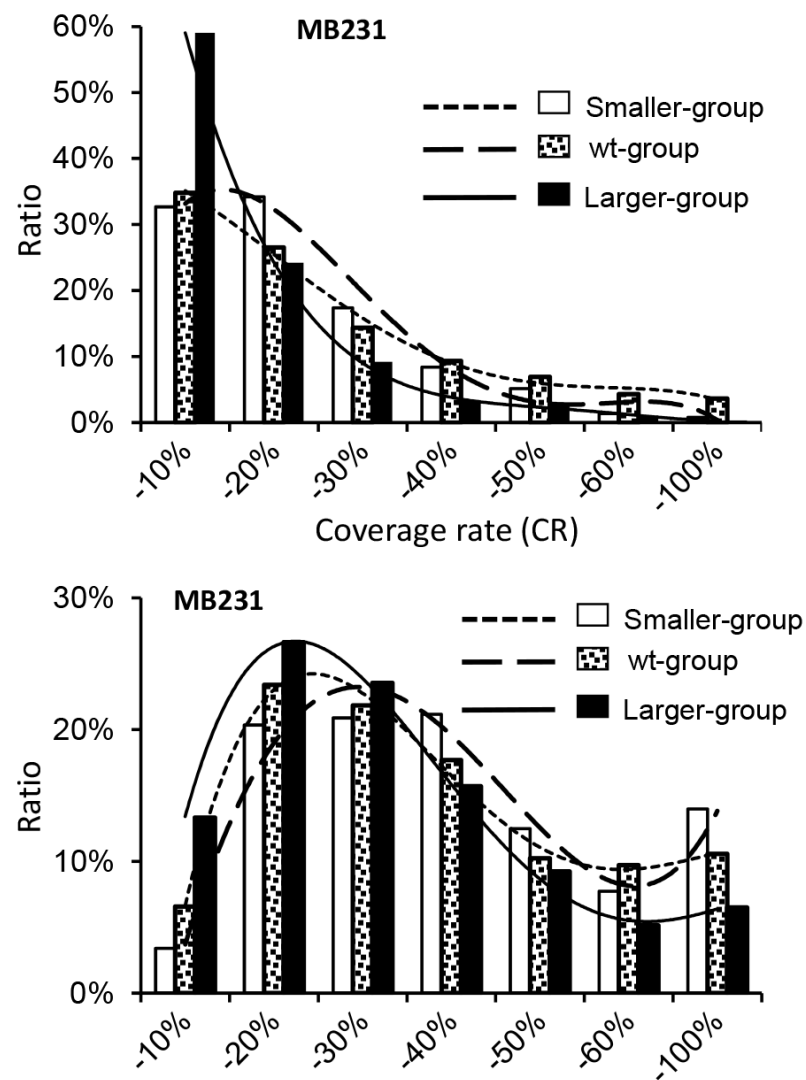

Approximate coverage of truncated protein (ACTP)

Figure 2: Coverage rate (CR) and approximate coverage of truncated protein (ACTP) of the proteins from different stripes from MB231 or MCF7 cells. 
Table 5: Number of proteins identified in only one single stripe

\begin{tabular}{lcccccc}
\hline Stripe & \multicolumn{2}{c}{ MCF7 } & \multicolumn{2}{c}{ MB231 } \\
\cline { 2 - 6 } & Total & Unique (\%) & $\begin{array}{c}\text { WT unique (\% of } \\
\text { total) }\end{array}$ & Total & Unique (\%) & $\begin{array}{c}\text { WT unique (\% of } \\
\text { total) }\end{array}$ \\
\hline $48 \mathrm{kD}$ & 470 & $183(38.9 \%)$ & $42(8.9 \%)$ & 765 & $223(29.2 \%)$ & $85(11.1 \%)$ \\
$55 \mathrm{kD}$ & 390 & $50(12.8 \%)$ & $11(2.8 \%)$ & 750 & $134(17.9 \%)$ & $76(10.1 \%)$ \\
$72 \mathrm{kD}$ & 490 & $173(35.3 \%)$ & $54(11.0 \%)$ & 678 & $260(38.3 \%)$ & $108(15.9 \%)$ \\
All & 1350 & $406(30.1 \%)$ & $107(7.9 \%)$ & 2193 & $617(28.1 \%)$ & $269(12.3 \%)$ \\
stripes & & & & & &
\end{tabular}

cell lines, i.e. the $24.6 \%$ and $22.7 \%$, got $23.7 \%$, or about one-fourth.

A significantly larger number of proteins appeared in two neighboring stripes than in two more-distant stripes, i.e. more proteins appeared in both $48 \mathrm{kD}$ and $55 \mathrm{kD}$ and in both $55 \mathrm{kD}$ and $72 \mathrm{kD}$ than in both $48 \mathrm{kD}$ and $72 \mathrm{kD}$ (Table 4). This result suggests not only that the appearance of the same-gene-derived proteins in two different positions of SDS-PAGE is less-likely due to random degradation but also that different protein isoforms more often have a relatively smaller, than a larger, difference in their size, as we explained before [12].

\section{Examples of protein multiplicity included PLEC, AHNAK, histone $4 \mathrm{H}$ and cytochrome $\mathrm{C}$}

Plectin-isoform-1 gene (PLEC) has 22 mRNA variants listed in the NCBI database that encode 22 protein isoforms varying between 3429-4684 AAs, with the WT protein of 4684 AAs weighing $531.5 \mathrm{kD}$. We detected PLEC protein in all three stripes from both cell lines, with great differences between the two cell lines and among the three stripes from the same cell line, in the number and dispersion of the LC-MS/MS-detected peptides (Figure 3 and Supplementary Data 2): In MB231 cells, the detected peptides were localized roughly to the middle region of PLEC in the $48 \mathrm{kD}$ stripe but to the vicinity of the boundary between the N-terminal and middle regions in the $55 \mathrm{kD}$ and $72 \mathrm{kD}$ stripes. In contrast, there were many more LC-MS/MS-detected peptides that were widely distributed across PLEC protein from the three stripes from MCF7 cells. However, a caveat needs to be given that our method is not an authentic top-down approach and thus it cannot be ruled out that more than one isoform existed in the same stripe from MCF7 cells.

Another gene, "neuroblast differentiation-associated protein AHNAK isoform 1", has nine mRNAs and also nine protein isoforms listed in the NCBI database. One isoform is as short as 149 AAs with a TMM of $\sim 16 \mathrm{kD}$, while the remaining eight isoforms vary between 40735890 AAs with their TMMs varying between 433-629 $\mathrm{kD}$. Although these nine isoforms are either too small or too large to appear in any of our gel stripes, AHNAK was detected in almost all stripes from both cell lines expect the $55 \mathrm{kD}$ stripe from MCF7 cells (Figure 4 and Supplementary Data 2). In the three stripes from MB231 cells, the LCMS/MS-detected peptides were localized roughly to the $\mathrm{N}$ - and $\mathrm{C}$-terminal regions with a large middle region varying from 5040 to 5220 AAs without any detected peptide (Figure 4). In contrast, in the $48 \mathrm{kD}$ and $72 \mathrm{kD}$ stripes from MCF7 cells, the LC-MS/MS-detected peptides were localized roughly to the middle region, although there still were large regions without any detected peptide (Figure 4). Moreover, in the $48 \mathrm{kD}$ stripe from MCF7 cells, there were only two unique peptides detected, i.e. the AEGPEVDVNLPK and the VDIEGPDVNIEGPEGK sequences, but the AEGPEVDVNLPK had six repeats while the VDIEGPDVNIEGPEGK had two repeats detected. In the $72 \mathrm{kD}$ stripe from MCF7 cells, there were five unique peptides detected, one of which had one repeat and three of which had multiple repeats (Figure 4). These repeats raise the possibility that the actual AHNAK protein(s) in the stripe might not be as large as shown in Figure 4, since these repeated peptides might only come from one or some, but not all, regions of AHNAK. Moreover, there might be more than one isoform in each stripe, each of which might be relatively small.

We mapped LC-MS/MS identified peptides onto the 40 proteins with the largest TMMs from each stripe of each cell line (Supplementary Data 2), and found that many proteins had large region(s) without any LC-MS/MSidentified peptide, similar to PLEC and AHNAK proteins. This finding dovetails with our previous observations at lower (26-40 kD) ranges of SDS-PAGE [12]. Since it is unlikely that such a large region lacks a trypsin digestion site, we conclude that these regions may not actually be present in the proteins, due to various reasons such as alternative splicing of RNA or proteolysis of protein, which in turn might be a reason why many proteins were detected at a much lower position of SDS-PAGE than their TMMs. As exemplified by PLEC and AHANK, in most of these 40 proteins with the largest TMMs, LC-MS/MSidentified peptides for the same genes were not identical among different stripes from the same cell line or between the stripes at the same molecular weight from different cell lines (Supplementary Data 2). One possible explanation is 
that different protein isoforms of the same gene, such as the PLEC, exist in different stripes from the same cell line or exist in the same stripe from different cell lines.

According to the NCBI database, the histone H4 (HIST1H4A) gene is only expressed to one mRNA that produces only one protein with a TMM of $11.4 \mathrm{kD}$, which should not appear in any of the three stripes. However, it was detected from all three stripes from both cell lines (Figure 5), suggesting that besides the $11.4 \mathrm{kD}$ WT protein (if it was expressed), it may have at least three larger isoforms. Similarly, the NCBI database shows that the cytochrome c
(CYCS) gene has only one mRNA that produces only one protein of $11.7 \mathrm{kD}$, but it was detected in all three stripes from MB231 cells, suggesting that it might have three larger isoforms, besides the WT protein at $11.7 \mathrm{kD}$ needed by the cell. Cytochrome $\mathrm{c}$ was not detected in any of the three stripes from MCF7 cells, which most likely suggests that these larger isoforms may be cell-line specific, unlike the histone $\mathrm{H} 4$. We mapped LC-MS/MS identified peptides onto 20 proteins with the smallest TMMs from each stripe from each cell line, and found many cases similar to histone $\mathrm{H} 4$ and cytochrome c (Supplementary Data 2).

>gi $|41322916|$ ref |NP_958782.1| plectin 1 isoform 1 [Homo sapiens] (531.5 kD)

2880-AAs-deleted/RNRRLTVNEAVKEGVVGPELHHKLLSAERAVTGYKDPYTGQQISLFQAMQKGLIVREHGIRLLEAQIATGGVIDPVHSHRVPVDVAYRRGYFDEE MNRVLADPSDDTKGFFDPNTHENLTYLQLLERCVEDPETGLCLLPLTDKAAKGGELVYTDSEARDVFEKATVSAPFGKFOGKTVT/1624-AAs-deleted [48kDMB231 cells]

270-AAs-deleted/LGLIWTI ILHFQISDIQVSGQSEDMTAKEKLLLWSQRMVEGYQGLRCDNFTSSWRDGRLFNAIIHRHKPLLIDMNKVYRQTNLENLDQAFSVAERD LGVTRLLDPEDVDVPQPDEKS I TYYSSLYDAMPRVPDVQDGVRANELQLRWQEYRELVLLLLQWMRHHTAAFEERRFPSSFEE /4234-AAS-deleted [55kDMB231 cells]

360-AAS-deleted/SVAERDLGVTRLLDPEDVDVPQPDEKSI ITYVSSLYDAMPRVPDVQDGVRANELQLRWQEYRELVLLLLQWMRHHTAAFEERRFPSSFEEIEILWS QFLKFKEMELPAKEADKNRSKGIYQSLEGAVQAGQLKVPPGYHPLDVEKEWGKLHVAILEREKQLRSEFERLECLQRIVTKLQMEAGLCEEQLNQADALLQSDVRLLAAGKV PQRAGEVERDLDKADSMIRLLFNDVQTLKDGRHPQGEQMYRRVYRLHERLVAIRTEYNLRLK_4054-AAs-deleted [72kD-MB231 Cells]

180-AAs-deleted/QKKTFTKWVNKHLIKAQRHISDLYEDLRDGHNLISLLEVLSGDSLPREKGRMRFHKLQNVQIALDYLRHRQVKLVNIRNDDIADGNPKLTLGLIWT IILHFQISDIQVSGQSEDMTAKEKLLLWSQRMVEGYQGLRCDNFTSSWRDGRLFNAIIHRHKPLIIDMNKVYRQTNLENLDQAFSVAERDLGVTRLLDPEDVDVPQPDEKSI I TYVSSLYDAMPRVPDVQDGVRANELQLRWQEYRELVLLLLQWMRHHTAAFEERRFPSSFEEIEI LWSQFLKFKEMELPAKEADKNRSKGIYQSLEGAVQAGQLKVPPGYHP LDVEKEWGKLHVAILEREKQLRSEFERLECLQRIVTKLQMEAGLCEEQLNQADALLQSDVRLLAAGKVPQRAGEVERDLDKADSMIRLLFNDVQTLKDGRHPQGEQMYRRVY RLHERLVAIRTEYNLRLK/2250-AAs - deleted/RNRRLTVNEAVKEGVVGPELHHKLLSAERAVTGYKDPYTGOOISLFOAMOKGLIVREHGIRLLEAOIATGGVIDPV HSHRVPVDVAYRRGYFDEEMNRVLADP SDDTKGFFDPNTHENLTYLQLLERCVEDPETGLCLLPLTDKAAKGGELVYTDSEARDVFEKATVSAPFGKFQGKTVT /540-AAS - deleted/LLEAQIATGGI IDPVHSHRVPVDVAYQRGYFSEEMNRVLADPSDDTKGFFDPNTHENLTYRQLLERCVEDPETGLRLLPLKGAEKAEVVETTQVYTEEETRRA FEETQIDIPGGGSHGGSTMSLWEVMQSDL I PEEQRAQLMADFQAGRVTKERMI I I I IEI IEKTE I IRQQGLASYDYVRRRLTAEDLFEARI ISLETYNLLREGTRSLREALE AESAWCYLYGTGSVAGVYLPGSRQTLSIYQALKKGLLSAEVARLLLEAQAATGFL/814-AAs-deleted [48kD-MCF7]

180-AAs-deleted/QKKTFTKWVNKHLIKAQRHISDLYEDLRDGHNLISLLEVLSGDSLPREKGRMRFHKLQNVQIALDYLRHRQVKLVNIRNDDIADGNPKLTLGLIWT IILHFQISDIQVSGQSEDMTAKEKLLLWSQRMVEGYQGLRCDNFTSSWRDGRLFNAI IHRHKPLI IDMNKVYRQTNLENLDQAFSVAERDLGVTRLLDPEDVDVPQPDEKS I ITYVSSLYDAMPRVPDVQDGVRANELQLRWQEYRELVLLLLQWMRHHTAAFEERRFPSSFEEIEILWSQFLKFKEMELPAKEADKNRSKGIYQSLEGAVQAGQLKVPPGYHP LDVEKEWGKLHVAILEREKQLRSEFERLECLQRIVTKLQMEAGLCEEQLNQADALLQSDVRLLAAGKVPORAGEVERDLDKADSMIRLLFNDVQTLKDGRHPQGEOMYRRVY RLHERLVAIRTEYNLRLK/990-AAs-deleted/EAEAOKROAOEEAERLRROVQDESORKRQAEVELASRVKAEAEAAREKQRALQALEELRLQAEEAERRLRQAEVERA RQVQVALETAQRSAEAELQSKRASFAEKTAQLERSLQEEHVAVAQLREEAERRAQQQAEAERAREEAERELERWQLKANEALRLRLQAEEVAQQKSLAQAEAEKQKEEAERE ARRRGKAEEQAVRQRELAEQELEKQRQLAEGTAQQRLAAEQELIRLRAETEQGEQQRQLLEEELARLQREAAAATQKRQELEAELAKVRAEMEVLLASKARAEEESRSTSEK SKQRLEAEAGRFRELAEEAARLRALAEEAKRQRQLAEEDAARQRAEAERVLAEKLAA IGEATRLKTEAEIALKEKEAENERLRRLAEDEAFQRRRLEEQAAQHKADIEERLA OLRKASDSELEROKGLVEDTLRORROVEEEILALKAS /810-AAS-deleted/RNRRLTVNEAVKEGVVGPELHHKLLSAERAVTGYKDPYTGOOISLFOAMOKGLIVREH GIRLLEAQIATGGVIDPVHSHRVPVDVAYRRG $/ 630$-AAS-deleted/LLEAQIATGGI IDPVHSHRVPVDVAYQRGYFSEEMNRVLADPSDDTKGFFDPNTHENLTYRQI LERCVEDPETGLRLLPLKGAEKAEVVETTQVYTEEETRRAFEETQIDIPGGGSHGGSTMSLWEVMQSDLI PEEQRAQLMADFQAGRVTKERMI I I I IE I IEKTE I IRQQGLA SYDYVRRRLTAEDLFEARIISLETYNLLREGTRSLREALEAESAWCYLYGTGSVAGVYLPGSRQTLSIYQALKKGLLSAEVARLLLEAQAATGFLLDPVKGERLTVDEAVRK GLVGPELHDRLLSAERAVTGYRDPYTEQTISLFQAMKKELIPTEEALRLLDAQLATGGIVDPRLGFHLPLEVAYQRGYLNKDTHDQLSEPSEVRSYVDPSTDERLSYTOLLR RCRRDDGTGQLLLPLSDARKLTFRGLRKOITMEELVRSOVMDEATALOLREGLTSIEEVTKNLOKFLEGTSCIAGVFVDATKERLSVYOAMKKGI IRPGTAFELLEAOAATG YVIDPI KGLKL TVEEAVRMGIVGPEFKDKLLSAERAVTGYKDPYSGKLISLFQAMKKGLILKDHGIRLLEAQIATGGI IDPEESHRLPVEVAYKRGLFDEEMNE ILTDPSDD TKGF FDPNTEENLTYLQLMERCITDPQTGLCLLPLKEKKRERKTSSKSSVRKRRVVIVDPET GKEMSVYEAYRKGLIDHQTYLELSEQECEWEE ITISSSDGVVKSMI IDRR SGRQYDIDDAIAKNLIDRSALDQYRAGTLSITEFADMLSGNAGGFRSRSSSVGSSSSYPISPAVSRTQLASWSDP L274-AAs-deleted [55kD-MCF7 cells]

270-AAs-deleted/LGLIWTI ILHFQISDIQVSGQSEDMTAKEKLLLWSQRMVEGYQGLRCDNFTSSWRDGRLFNAIIHRHKPLLIDMNKVYRQTNLENLDQAFSVAERD LGVTRLLDPEDVDVPQPDEKS I ITYVSSLYDAMPRVPDVQDGVRANELQLRWQEYRELVLLLLQWMRHHTAAFEERRFPSSFEEIEILWSQFLKFKEMELPAKEADKNRSKG IYQSLEGAVQAGQLKVPPGYHPLDVEKEWGKLHVAILEREKQLRSEFERLECLQRIVTKLQMEAGLCEEQLNQADALLQSDVRLLAAGKVPQRAGEVERDLDKADSMIRLLF NDVQTLKDGRHPQGEQMYRRVYRLHERLVAIRTEYNLRLK/1800-AAs-deleted/RQLAEEDLAQQRALAEKMLKEKMQAVQEATRLKAEAELLQQQKELAQEQARRLQ EDKEQMAQQLAEETQGFQRTLEAERQRQLEMSAEAE/360-AAs-deleted/RNRRLTVNEAVKEGVVGPELHHKLLSAERAVTGYKDPYTGQQISLFQAMQKGLIVREHG IRLLEAOIATGGVIDPVHSHRVPVDVAYRRGYFDEEMNRVLADPSDDTKGFFDPNTHENLTYLOLLERCVEDPETGLCLLPLTDKAAKGGELVYTDSEARDVFEKATVSAPF GKFQGKTVT/720-AAS-deleted/RRRLTAEDLFEARIISLETYNLLREGTRSLREALEAESAWCYLYGTGSVAGVYLPGSRQTLSIYQALKKGLLSAEVARLLLEAQAA TGFLLDPVKGERLTVDEAVRKGLVGPELHDRLLSAERAVTGYRDPYTEQTISLFQAMKKELIPTEEALRLLDAQLATGGIVDPRLGFHLPLEVAYQRGYLNKDTHDQLSEPS EVRSYVDPSTDERLSYTQLLRRCRRDDGTGQLLLPLSDARKLTFRGLRKQITMEELVRSQVMDEATALQLREGLTS IEEVTKNLQKFLEGTSCIAGVFVDATKERLSVYQAM KKGI IRPGTAFELLEAOAATGYVIDPIKGLKLTVEEAVRMGIVGPEFKDKLLSAERAVTGYKDPYSGKL ISLFQAMKKGLILKDHGIRLLEAQIATGGI IDPEESHRLPVEV AYKRGLFDEEMNE ILTDPSDDTKGFFDPNTEENLTYLQLMERCITDPOTGLCLLPLKEKKRERKTSSKSSVRKRRVVIVDPETGKEMSVYEAYRKGLIDHOTYLELSEOECE WEEITISSSDGVVKSMI IDRRSGRQYDIDDAIAKNLIDRSALDQYRAGTLSITEFADMLSGNAGGFRSRSSSVGSSSSYPISPAVSRTQLASWSDPTEETGPVAGILDTETL EKVS ITEAMHRNLVDNITGQRLLEAQACTGGIIDPSTGERFPVTDAVNKGLVDKIMVDRINLAQKAFCGFEDPRTKTKMSAAQALKKGWLYYEAGQRFLEVQYLTGGLIEPD TPGRVPLDEALQRGTVDARTAQKLRDVGAYSKYLTCPKTKLKISYKDALDRSMVEEGTGLRLLEAAAQSTKGYYSPYSVSGSGSTAGSRTGSRTGSRAGSRRGSFDATGSGF SMTFSSSSYSSSGYGRRYASGSSASLGGPESAVA [72kD-MCF7]

Figure 3: Sequences with the LC-MS/MS-detected (boldfaced and shaded) peptides that are unique to the Plectin-1 isoform 1 (PLEC), with the regions lacking any detected peptide not shown (i. e. deleted to shorten the length). A peptide (LLEAQIATGGVIDPVHSHRVPVDVAYR; boldfaced and underlined) that is not unique to PLEC (and might also appear in other proteins) was also detected in the $72 \mathrm{kD}$ stripe from MCF7 cells. In all three stripes from MB231 cells, these detected peptides are mainly localized to the middle region of PLEC. In contrast, in all three stripes from MCF7 cells, the detected peptides are localized to the N- and C-terminal regions, but not to the middle region, roughly speaking. 


\section{DISCUSSION}

\section{There are usually many unmatchable inputs in LC-MS/MS data}

In all LC-MS/MS studies of proteins, there is always a large percentage of clear inputs that cannot be matched to the peptide reference. As discussed before [12], the reasons for this phenomenon have not yet been fully clarified but are likely to be multiple, including technical artifacts. One reason may be that all current algorithms for translation of mRNA to protein have many flaws and cannot annotate many protein-coding mRNAs [2, 12]. Indeed, protein products of a large number of already-annotated genes have not yet been identified [13], and all algorithms exclude those open reading frames smaller than 100 codons, although the existence of proteins much shorter than 100 AAs has been well documented [4-16]. Moreover, most, if not all, algorithms use only 20 amino acids shown on the genetic

>gi $|61743954|$ ref|NP_001611.1| neuroblast differentiation-associated protein AHNAK isoform 1 [Homo sapiens] (628.7 $\mathrm{kD})$

MEKEETTRELLLPNWQGSGSHGLTIAQRDDGVFVQEVTONSPAARTGVVKEGDQIVGATIYFDNLQSGEVTQLLNTMGHHTVGLKLHRKGDRSPEPGQTWTREVFSSCSSEVV LSGDDEEYQRIYTTKIKPRLKSEDGVEGDLGETQSRTITVTRRVTAYTVDVTGREGAKDIDISSPEFKIKIPRHELTEISNVDVETQSGKTVIRLPSGSGAASPTGSAVDIRA GAISASGPELQGAGHSKLQVTMPGIKVGGSGVNVNAKGLDLGGR_5220-AAs-deleted/NLQMPGIKSSGCDVNLPGVNVKLPTGQISGPEIKGGLKGSEVGFHGAAPDI SVKGPAFNMASPESDFGINLKGPKIKGGADVSGGVSAPDISLGEGHLSVKGSGGEWKGPQVSSALN_283-AAs-deleted [48kD-MB231 cells]

MEKEETTRELLLPNWQGSGSHGLTIAQRDDGVFVQEVTQNSPAARTGVVKEGDQIVGATIYFDNLQSGEVTQLLNTMGHHTVGLKLHRKGDRSPEPGQTWTREVFSSCSSEVV LSGDDEEYQRIYTTKIKPRLKSEDGVEGDLGETQSRTITVTRRVTAYTVDVTGREGAKDIDISSPEFKIKIPRHELTEISNVDVETQSGKTVIRLPSGSGAASPTGSAVDIRA GAISA.SGPELQGAGHSKLQVTMPGIKVGGSGVNVNAKGLDLGGR/5220-AAs-deleted/NLQMPGIKSSGCDVNLPGVNVKLPTGQISGPEIKGGLKGSEVGFHGAAPDI SVKGPAFNMASPESDFGINLKGPKIKGGADVSGGVSAPDISLGEGHLSVKGSGGEWKGPQVSSALN L283-AAs-deleted [55kD-MB231 cells]

MEKEETTRELLLPNWQGSGSHGLTIAQRDDGVFVQEVTQNSPAARTGVVKEGDQIVGATIYFDNLQSGEVTQLLNTMGHHTVGLKLHRKGDRSPEPGQTWTREVFSSCSSEVV LSGDDEEYQRIYTTKIKPRLKSEDGVEGDLGETQSRTITVTRRVTAYTVDVTGREGAKDIDISSPEFKIKIPRHELTEISNVDVETQSGKTVIRLPSGSGAASPTGSAVDIRA GAISASGPELQGAGHSKLQVTMPGIKVGGSGVNVNAKGLDLGGR/5040-AAs- deleted/LKGDLDASVPSMKVHAPGLNLSGVGGKMQVGGDGVKVPGIDATTKLNVGAP DVTLRGPSLQGDLAVSGDIKCPKVSVGAPDLSLEASEGSIKLPKMKLPQFGISTPGSDLHVNAKGPQVSGELKGPGVDVNLKGPRISAPNVDFNLEGPKVKGSLGATGE I KGP TVGGGLPGIGVQGLEGNLQMPGIKSSGCDVNLPGVNVKLPTGQISGPEIKGGLKGSEVGFHGAAPD _350-AAs-deleted [72kD-MB231 cells]

720-AAs-deleted/KLEGELKGPKVDIDAPDVDVHGPDWHLKMPKMKMPKFSVPGFKAEGPEVDVNLPKADVDISGPKIDVTAPDVS IEEPEGKLKGPKFKMPEMNI KVPK ISMPDVDLHLKGPNVKGEYDVTMPKVESEIKVPDVELKSAKMDIDVPDVEVQGPDWHLKMPKMKMPKF SMPGFKAEGPEVDVNLPKADVDISGPKVGVEVPDVNIEGPEGKLK GPKFKMPEMNIKAPKISMPDVDLHMKGPKVKGEYDMTVPKLEGDLKGPKVDVSAPDVEMQ/720-AAs-deleted/KMPKMKMPKFSMPGFKAEGPEVDVNLPKADIDVSGP SVDTDAPDLDIEGPEGKLKGSKF KMPKLNIKAPKVSMPDVDLNLKGPKLKGEIDASVPELEGDLRGPQVDVKGPFVEAEVPDVDLECPDAKLKGPKFKMPEMHFKAPKI SMPD VDLHLKGPKVKGDADVSVPKLEGDLTGPSVGVEVPDVELECPDAKLKGPKFKMPDMHFKAPKISMPDVDLHLKGPKVKGDVDVSVPKLEGDLTGPSVGVEVPDVELECPDAKI KGPKFKMPEMHFKTPKISMPDVDLHLKGPKVKGDMDVSVPKVEGEMKVPDVDIKGPKMDIDAPDVDVHGPDWHLKMPKMKMPKFSMPGFKAEGPEVDVNLPKADVVVSGPKVD 1425-AAs-deleted/PKMKMPKFSMPGFKAEGPEVDVNLPKADVDISGPKVDIEGPDVNIEGPEGKLKGPKLKMPEMNIKAPKISMPDFDLHLKGPKVKGDVDVSLPKVEG DLKGPEVDI KGPKVDINAPDVGVQGPDWHLKMPKVKMPKF SMPGFKGEGPDGDVKLPKADIDVSGPKVDIEGPDVNIEGPEGKLKGPKFKMPEMNIKAPKISMPDIDLNLKGP KVKGDVDVSLPKVEGDLKGPEVDIKGPKVDIDAPDVDVHGPDWHLKMPKIKMPKISMPGFKGEGPDVDVNLPKADIDVSGPKVDVECPDVNIEGPEGKWKS PKFKMPEMHFKT PKISMPDIDLNLTGPKIKGDVDVTGPKVEGDLKGPEVDLKGPKVDIDVPDVNVQGPDWHLKMPKMKMPKFSMPGFKAEGPEVDVNLPKADVDVSGPKVDVEGPDVNIEGPEGK LKGPKFKMPEMNIKAPKIPMPDFDL L2920-AAs-deleted [48kD-MCF7 cells]

720-AAs-deleted/KLEGELKGPKVDIDAPDVDVHGPDWHLKMPKMKMPKFSVPGFKAEGPEVDVNLPKADVDISGPKIDVTAPDVS IEEPEGKLKGPKFKMPEMNI KVPK ISMPDVDLHLKGPNVKGEYDVTMPKVESEI KVPDVELKSAKMDIDVPDVEVQGPDWHLKMPKMKMPKF SMPGFKAEGPEVDVNLPKADVDISGPKVGVEVPDVNIEGPEGKLK GPKFKMPEMNIKAPKISMPDVDLHMKGPKVKGEYDMTVPKLEGDLKGPKVDVSAPDVEMQ_720-AA.s-deleted/KMPKMKMPKFSMPGFKAEGPEVDVNLPKADIDVSGP SVDTDAPDLDIEGPEGKLKGSKFKMPKLNIKAPKVSMPDVDLNLKGPKLKGEIDASVPELEGDLRGPQVDVKGPFVEAEVPDVDLECPDAKLKGPKFKMPEMHFKAPKISMPD VDLHLKGPKVKGDADVSVPKLEGDLTGPSVGVEVPDVELECPDAKLKGPKFKMPDMHFKAPKISMPDVDLHLKGPKVKGDVDVSVPKLEGDLTGPSVGVEVPDVELECPDAKI KGPKFKMPEMHFKTPKISMPDVDLHLKGPKVKGDMDVSVPKVEGEMKVPDVDIKGPKMDIDAPDVDVHGPDWHLKMPKMKMPKFSMPGFKAEGPEVDVNLPKADVVVSGPKVD VEVPDVSLEGPEGKLKGPKLKMPEMHFKAPKI SMPDVDLHLKGPKVKGDVDVSLPKLEGDLTGPSVDVEVPDVELECPDAKLKGPKFKMPEMHFKTPKISMPDVNLNLKGPKV KGDMDVSVPKVEGEMKVPDVDIRGPKVDIDAPDVDVHGPDWHLKMPKMKMPKFSMPGFKGEGPEVDVNLPKADVDVSGPKVDVEVPDVSLEGPEGKLKGPKFKMPEMHFKTPK ISMPDVDFNLKGPKIKGDVDVSAPKLEGELKGPELDVKGPKLDADMPEVAVEGPNGKWKTPKFKMPDMHFKAPKISMPDLDLHLKSPKAKGEVDVDVPKLEGDLKGPHVDVSG PDIDIEGPEGKLKGPKFKMPDMHFKAPNISMPDVDLNLKGPKI KGDVDVSVPEVEGKLEVPDMNIRGPKVDVNAPDVQAPDWHLKMPKMKMPKFSMPGFKAEGPEVDVNLPKA DVDISGPKVDIEGPDVNIEGPEGKLKGPKLKMPEMNI KAPKISMPDFDLHLKGPKVKGDVDVSLPKVEGDLKGPEVDIKGPKVDINAPDVGVQGPDWHLKMPKVKMPKFSMPG FKGEGPDGDVKLPKADIDVSGPKVDIEGPDVNIEGPEGKLKGPKFKMPEMNIKAPKISMPDIDLNLKGPKVKGDVDVSLPKVEGDLKGPEVDIKGPKVDIDAPDVDVHGPDWH LKMPKIKMPKISMPGF KGEGPDVDVNLPKADIDVSGPKVDVECPDVNI EGPEGKWKS PKFKMPEMHFKTPKISMPDIDLNLTGPKIKGDVDVTGPKVEGDLKGPEVDLKGPKV DIDVPDVNVQGPDWHLKMPKMKMPKFSMPGFKAEGPEVDVNLPKADVDVSGPKVDVEGPDVNIEGPEGKLKGPKFKMPEMN IKAPKI PMPDFDLHLKGPKVKGDVDISLPKVE GDLKGPEVDIRGPQVDIDVPDVGVQGPDWHLKMPKVKMPKFSMPGFKGEGPDVDVNLPKADLDVSGPKVDIDVPDVNIEGPEGKLKGPKFKMPEMNIKAPKISMPDIDLNLKG PKVKGDMDVSLPKVEGDMKVPDVDIKGPKVDINAPDVDVQGPDWHLKMPKI KMPKISMPGFKGEGPEVDVNLPKADLDVSGPKVDVDVPDVNIEGPDAKLKGPKFKMPEMNIK APKI SMPDLDLNLKGPKMKGEVDVSLANVEGDLKGPALDI KGPKIDVDAPDIDIHGPDAKLKGPKLKMPDMHVNMPKISMPEIDLNLKGSKLKGDVDVSGPKLEGDIKAPSLD IKGPEVDVSGPKLNIEGKSKKSRFKLPKFNFSGSKVOTPEVDVKGKKPDIDITGPKVDINAPDVEVOGKVKGSKFKMPFLSISSPKVSMPDVELNLKSPKVKGDLDIAGPNLE GDFKGPKVDIKAPEVNLNAPDVDVHGPDWNLKMPKMKMPKFSVSGLKAEGPDVAVDLPKGDINI EGPSMN IEGPDLNVEGPEGGLKGPKFKMPDMNIKAPKISMPDIDLNLKG PKVKGDVDISLPKLEGDLKGPEVDIKGPKVDINAPDVDVHGPDWHLKMPKVKMPKFSMPGFKGEGPEVDVTLPKADIDISGPNVDVDVPDVNIEGPDAKLKGPKFKMPEMNIK APKISMPDFDLNLKGPKMKGDVVVSLPKVEGDLKGPEVDIKGPKVDIDTPDINI EGSEGKFKGPKFKIPEMHLKAPKISMPDIDLNLKGPKVKGDVDVSLPKMEGDLKGPEVD IKGPKVDINAPDVDVQGPDWHLKMPKVKMPKFSMPGFKGEGPDVDVNLPKADLDVSGPKVDIDVPDVNIEGPEGKLKGPKFKMPEMNIKAPKISMPDIDLNLKGPKVKGDMDV SLPKVEGDMQVPDLDIKGPKVDINAPDVDVRGPDWHLKMPKIKMPKISMPGFKGEGPEVDVNLPKADLDVSGPKVDVDVPDVNIEGPDAKLKGPKFKMPEMNIKAPKISMPDF DLHLKGPKVKGDVDVSLPKMEGDLKAPEVDIKGPKVDIDAPDVDVHGPDWHLKMPKVKMPKFSMPGFKGEGPEVDVNLPKADIDVSGPKVDIDTPDIDIHGPEGKLKGPKFKM PDLHLKAPKISMPEVDLNLKGPKMKGDVDVSLPKVEGDLKGPEVDIKGPKVDIDVPDVDVQGPDWHLKMPKVKMPKF SMPGFKGEGPDVDVNLPKADLDVSGPKVDIDVPDVN 4420-AAs-deleted/PKVKMPKFSMPGFKGEGPDVDVNLPKADIDVSGPKVDVDVPDVNIEGPDAKLKGPKFKMPEMSIKAPKISMPDIDLNLKGPKVKGDVDVTLPKVEG DLKGPEADIKGPKVDINTPDVD $\angle 1120$-AAs-deleted [72kD-MCF7 cells]

Figure 4: The LC-MS/MS-detected (boldfaced and shaded) peptides of AHNAK protein, with the regions lacking a detected peptide (shaded and underlined) not shown (i. e. deleted to shorten the length). In the three stripes from MB231 cells, the detected peptides were localized to the regions near the $\mathrm{N}$ - and C-termini, with a large (5040-5220 AAs) middle region without any detected peptide. In contrast, the detected peptides were localized to the N-terminal and middle regions, but not to the C-terminal region, in the $48 \mathrm{kD}$ and $72 \mathrm{kD}$ stripes from MCF7 cells. It was not detected in the $55 \mathrm{kD}$ stripe from MCF7 cells. Note that in the $48 \mathrm{kD}$ stripe from MCF7 cells there are actually only two peptide sequences detected, each (coded with a color) with repeats. Similarly, in the $72 \mathrm{kD}$ stripe there are actually only five different peptide sequences detected (coded with different colors), four of which have repeats. These repeats raise the possibility that the protein isoforms detected in these stripes may not be as large as shown in the figure, because some repeat-containing regions might not be there and because there may be more than one isoforms in the same gel stripe that were identified by LC-MS/MS collectively. 
code list, despite that there are at least 22 proteinogenic amino acids [17]. This situation in turn is because we still know too little about translation process, although we have known much more about gene transcription and RNA processes, including RNA splicing [2, 18, 19]. It cannot be ruled out that some of the unmatchable inputs reflect some unknown protein isoforms produced via different mechanisms, such as unknown cis- or transsplicing derived mRNAs, [2, 18, 19] unknown start or stop codon usage for protein translation, protein splicing, etc. In addition, translational errors [20], which occur more often in cancer cells, may also make some clear inputs unmatchable.

\section{Few genes are expressed to only the WT protein without a sibling isoform}

An important finding of our study is that only about $3-16 \%$, or on average $\sim 10 \%$, of the total proteins identified had their TMMs within the WT range and appeared solely in one stripe (Table 5), while the vast rest of the proteins either have a TMM far away from the WT range or appear also in other stripe(s). These results in general dovetail with the our previous findings that only about one-fourth to one-third of the proteins from HEK293 cells at the $26 \mathrm{kD}$ and $40 \mathrm{kD}$ of a SDSPAGE were at the WT range, regardless whether they appeared solely in the stripe [12]. Some of the proteins in the smaller-group, i.e. those appearing at a site of SDSPAGE lower than their TMMs, may be nonspecifically degraded products, but most of them may not be, in part because the chance for the nonspecifically degraded products appear fortunately in all the three gel positions we analyzed is very low, especially for many proteins, as reasoned before [12]. Moreover, altered proteolysis may occur in the cell lines used, due to genetic alterations occurring such as during the decades of culture of the cell lines used, which may also contribute to the appearance of some proteins in the smaller-group. The reasons for the occurrence of the larger-group, i.e. appearing at a position of SDS-PAGE higher than their
TMMs, are much less known, although some of them may derive from different types of post-translational modifications, as exemplified by glycosylation of mu opioid receptor [21]. Theoretically, all different types of post-translational modification can occur in a single protein, and one single type, typically phosphorylation, can occur at many sites of a single protein as well, which together can dramatically shift the position of a particular protein in SDS-PAGE. While this situation still awaits experimental verification, we surmise that it may not occur to a large percentage of proteins expressed in a single cell line. Moreover, adding all these posttranslational modifications together still may not explain the observation that some proteins like histone $\mathrm{H} 4$ and cytochrome are gel-shifted so greatly, from about $11 \mathrm{kD}$ to $72 \mathrm{kD}$.

Considering that we have only studied three narrow stripes, it is very likely that many of these $10 \%$ of genes may still have other protein products at other positions of the SDS-PAGE that were not analyzed herein. Therefore, the actual percentage of those genes that meet the two criteria, i.e. within the WT range and solely in one stripe, is very likely to be much smaller than $10 \%$. Moreover, expression of many genes has cell- or tissue-specificity and varies among different developmental, physiological and pathological situations, whereas we have only studied two cell lines herein and another cell line (HEK293) previously that were cultured in a routine condition. Therefore, the actual percentage may be much lower than $10 \%$ genome-wide and regardless of cell- and tissuespecificity and of different developmental, physiological and pathological situations. In other words, probably few genes produce only the WT protein without a sibling, although a recent analysis of some LC-MS/MS databases suggests that most highly expressed genes produce only a single dominant protein isoform [22]. Our astonishing conclusion awaits further verification by an authentic top-down LC-MS/MS approach [23, 24], especially the newer version [11]. A caveat needs to be given that a $10 \%$ divergence to each side of TMM is actually larger than

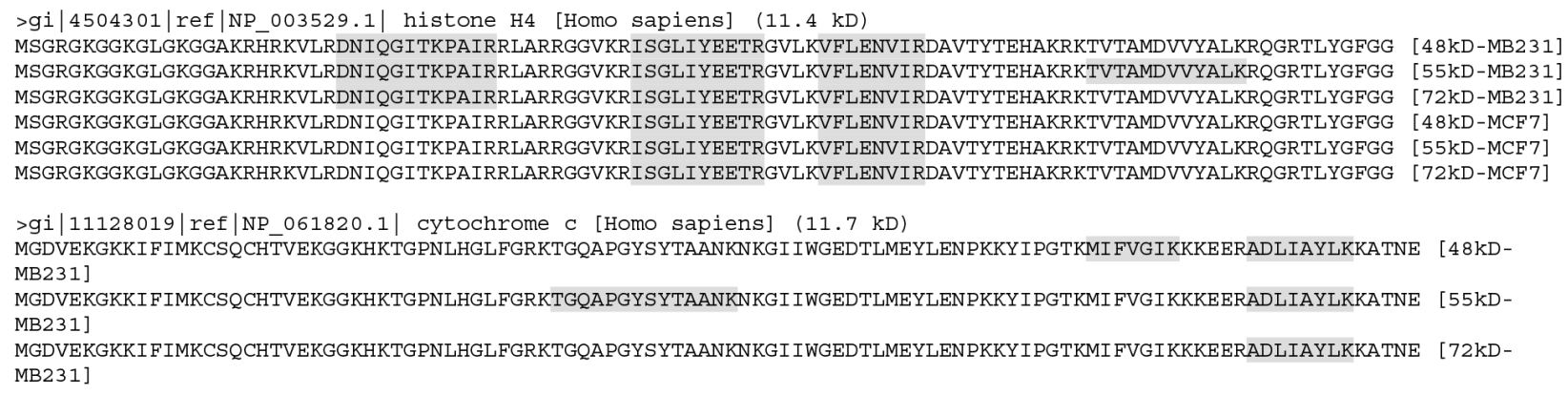

Figure 5: The LC-MS/MS-detected (boldfaces and shaded) peptides unique to the histone H4 (top panel) or cytochrome c (bottom panel). Note that the detected peptides of histone $\mathrm{H} 4$ were similar between the $48 \mathrm{kD}$ and $72 \mathrm{kD}$ stripes but differ between the $55 \mathrm{kD}$ stripe and these two stripes from MB231 cells. The detected peptides were the same among all the three stripes from MCF7 cells but differ from any of the stripes from MB231 cells. The detected sequences of cytochrome c differ among the three stripes from MB231 cells. 
most WB may produce. Narrowing it, such as to $5 \%$, will greatly shrink the WT-group and in turn enlarge the larger- and smaller-groups, making the conclusion even more astounding.

\section{Dispersion of identified peptides across to the WT protein is a useful criterion to distinguish different cells}

Unlike most proteomic studies using a LC-MS/MS approach, we localize LC-MS/MS-identified peptides onto the corresponding WT protein and calculate the CR and ACTP. A higher CR indicates that the protein isoform detected is closer to the WT form in terms of sequence length, or has a higher chance to be the WT form. As shown by examples in Figures 4 and 5, although proteins derived from the same gene were identified at the same position of SDS-PAGE from different cell lines, the differences in CR as well as in dispersion of identified peptides suggest that this gene may produce different protein isoforms in different cell lines. Therefore, mapping identified peptides onto the WT protein sequence to determine the dispersion and CR can be a good approach to distinguish different cells, even cells from the same tissue origin such as mammary gland derived MB231 and MCF7. This is of significance because distinguishing cells of the same tissue origin usually is not as easy as differentiating cells from different tissue origins. This approach utilizes a huge number of proteins as biomarkers and thus may be more reliable than the routine method that only uses single or several biomarkers. In addition, the distribution curve of LC-MS/MS-identified proteins according to their TMMs, as shown in Figure 1, may also be used as a collective biomarker to distinguish cells from the same tissue origin, as evidenced by the difference between the MB231 and MCF7 cells.

\section{In most cases of $\mathrm{WB}$, it creates a bias to cut away additional bands}

The overarching conclusion that few genes produces only the WT protein without additional isoform(s) challenges our routine practice of WB. In most published results of WB, only a narrow band on the membrane was presented, which implies to the readers that the isoform of interest, usually the WT form, is the sole one expressed. However, usually there are additional band(s) on the membrane but they are regarded as "artifacts" without a convincing proof and thus are cut away to make the data explanation more straightforward, as pointed out recently [4]. Even worse, blamed by the customers for selling "not

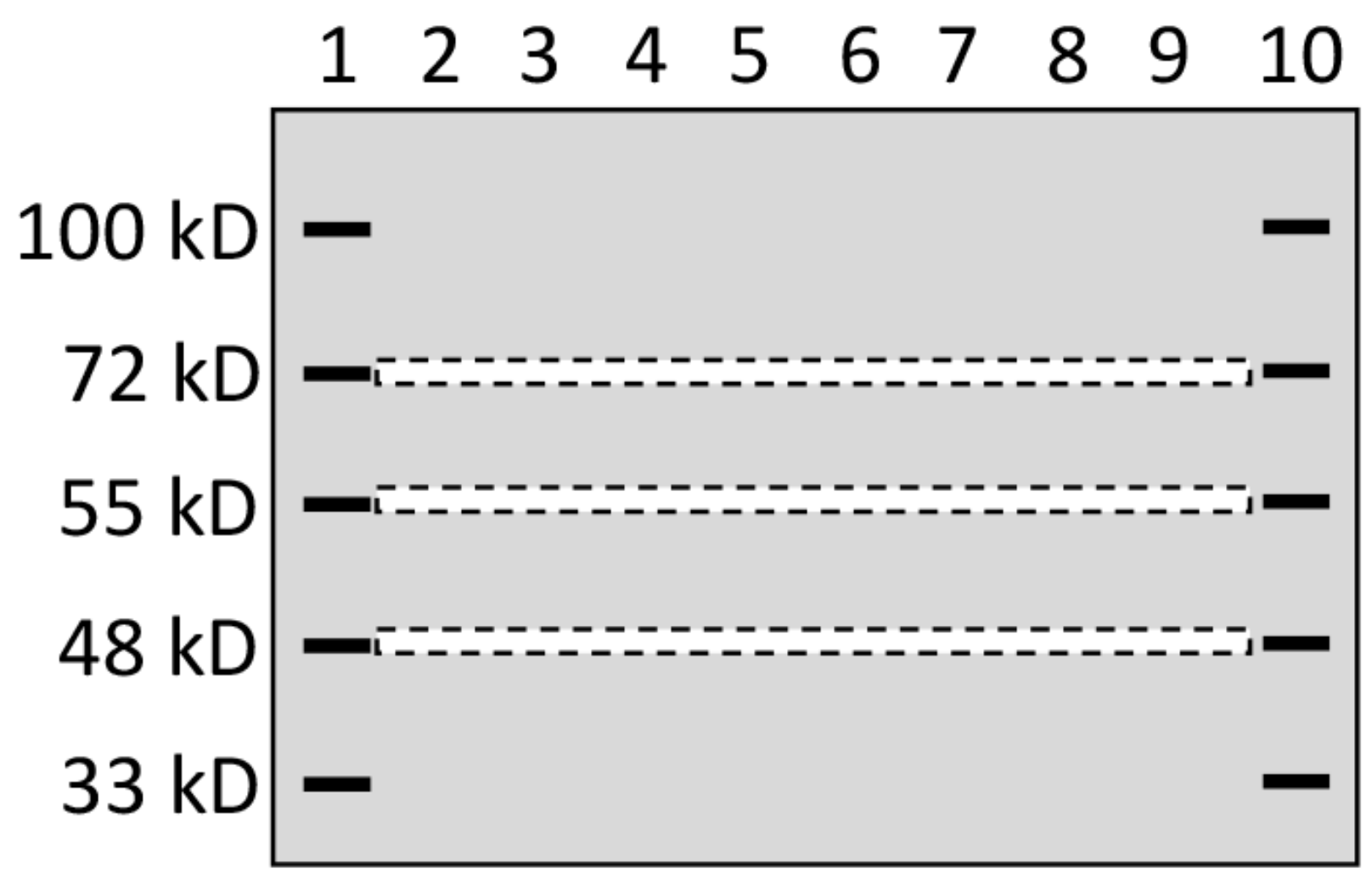

Figure 6: Depiction of gel stripe excision. A 10\% SDS-PAGE that was 2-cm longer in the vertical direction than regular minigels was loaded with a pre-stained protein marker in lanes 1 and 10 and with protein samples from one cell line in the lanes 2-9. After electrophoresis, narrow gel stripes of 2-mm in width (narrow dash-lined boxes) were excised out, using a surgical blade and with help of two rulers, for protein digestion and ensuing LC-MS/MS analysis. 
specific enough" antibodies, antibody producing companies try hard to select and market those antibodies that gave rise to only a single band on WB, while researchers also elect these "more specific" antibodies. This alliance between antibody suppliers and their customers will likely extinguish, via a "natural selection", those antibodies that react to more isoforms and, meanwhile, mislead the biomedical fraternity to a distorted picture of the gene in question. In our opinion, many, but certainly not all, of those antibodies blamed to have poor specificity may actually reflect more faithfully the truth and provide us with a better global picture of the gene in question. Actually, some published studies with WB did detect and presented some bands larger than the TMM [25]. In our practice of $\mathrm{WB}$, we routinely employ multiple antibodies and present all bands shown on the membrane [26-29].

\section{In most cases, correctly interpreting immunohistochemical data still remains impossible}

Another alert set off by our findings pertains to immunohistochemistry and even immunocytochemistry, because on a glass slide the specificity of the signals yielded by the antibody used cannot be authenticated by the molecular weight of the targeted protein. Protein multiplicity is often associated with cell-type specificity, subcellular specificity (i.e. varying among different organelles or locations within the cell), and situationspecificity [4]. For instance, a smaller isoform of cyclin $\mathrm{E}$ derived from proteolysis of the WT protein is mainly localized to the cytoplasm of cancer cells, while the WT protein is mainly localized to the nucleus [30]. Moreover, in a routine $\mathrm{WB}$, a protein is denatured but on a paraffinembedded section it has a conformation close to the native status, owing to a quick fixation by formalin. This disparity disqualifies WB from endorsing the specificity of an antibody for immunohistochemical staining of paraffinembedded sections. Because of these currently unsolved technical bottlenecks, although a positive signal resulting from a well-conducted staining is likely to indicate the presence of protein product(s) of the gene in question, in most cases it cannot tell which protein isoform(s) give rise to the signal. This situation greatly diminishes the power of immunohistochemistry in exploration into the biological function or mechanism of genes. The results and ensuing interpretations are convincing only in those studies on those well-characterized isoforms of wellcharacterized genes with a confirmed isoform-specific antibody, such as some p53 protein isoforms and some relevant antibodies [31]. Unfortunately, the number of such genes is very small, in sharp contrast to a plethora of published immunohistochemical data with antibodies not yet well-characterized for the isoform-specificity.

Few published studies involving immuno histochemical staining put enough attention on the protein multiplicity and confirm the isoform-specificity of the antibody used. In fact, many, if not most, researchers do not even know how many protein isoforms their target gene may produce and what similarity and disparity among these isoforms are, in terms of protein sequence. In most published studies on immunohistochemical data, the antibody used is assumed, although rarely declared, to recognize only a single protein isoform and thus all the positive staining is accredited to it. This situation greatly worries us as it has hardly been discussed in detail in the literature. Development of a good strategy to solve these technical bottlenecks is a prerequisite and an imperative for researchers to determine not only whether the gene of interest is expressed to a protein but also which protein isoform(s) are expressed.

\section{MATERIALS AND METHODS}

\section{Protein sample preparation}

MCF7 and MDA-MB231 (MB231) human breast cancer cell lines were cultured routinely in a Dulbecco's modified eagle medium containing $10 \%$ fetal bovine serum. As described before [12], cells at about $80 \%$ confluence were washed with $1 \mathrm{x}$ phosphate buffered saline and then harvested via scraping in a lysis buffer containing 1x Proteinase Inhibitor Cocktail (SigmaAldrich, Inc, St. Louis, MS). After centrifugation to precipitate insoluble components, proteins were collected and diluted with a gel-loading buffer containing $2 \%$ SDS and $2 \% 2$-mercaptoethanol as the final concentration. The protein samples were boiled for $5 \mathrm{~min}$ and then quickly cooled down on ice.

\section{SDS-PAGE and protein collection}

To better separate the proteins, a 10\% SDS-PAGE was made with $10 \times 10.5 \mathrm{~cm}$ glass plates included in the Hoeffer SE260 vertical slab gel system (Hoeffer Inc; http://www.hoeferinc.com/), which produced a gel $2-\mathrm{cm}$ longer in the vertical direction than the gel made using regular mini-gel cast systems of Hoeffer and other companies. The first and last wells of the gel were loaded with a pre-stained protein marker, while each remaining well was loaded with $50 \mu \mathrm{g}$ of protein sample as illustrated in Figure 6. One gel was loaded with proteins from MCF7 cells while another was loaded with proteins from MB231 cells. The two gels were electrophoresed at the same time using the same power supplier. Guided by two rulers, narrow stripes, each about 2-mm in width, were excised out with a surgical blade from the gel at positions of $72 \mathrm{kD}, 55 \mathrm{kD}$ and $48 \mathrm{kD}$ indicated by pre-stained markers, as illustrated in Figure 6. These positions were selected for several reasons: First, our pre-stained protein markers showed these positions, which allowed us to precisely excise a narrow gel stripe 
at these positions. Second, this $48-72 \mathrm{kD}$ range resides in the middle of the $10 \%$ gel cast using most-commonlyused mini-gel cast systems. This middle range still leaves us with a large region below $48 \mathrm{kD}$ and another region above $72 \mathrm{kD}$. Therefore, those $48-72 \mathrm{kD}$ WT proteins, which are more commonly studied in published papers, could be well differentiated from their isoforms at a much lower or higher molecular weight. Third, the 26-40 $\mathrm{kD}$ range has already been studied in our previous paper [12]. Fourth, proteins at higher positions (say higher than $100 \mathrm{kD}$ ) of a $10 \%$ gel cannot be well separated. In summary, these positions were selected after many technical issues were taken into consideration.

\section{LC-MS/MS}

The procedures for the sample preparation and the ensuing LC-MS/MS analysis were routine and were described in detail previously [12], and were conducted at Beijing Institute of Genomics, Chinese Academy of Sciences, Beijing, P.R. China. Briefly, the excised gel stripes were dehydrated with increasing concentrations of acetonitrile $(\mathrm{ACN})$. The in-gel proteins were reduced and alkylated with $10 \mathrm{mM}$ dithiothreitol and $55 \mathrm{mM}$ iodoacetamide and then digested with trypsin at $37{ }^{\circ} \mathrm{C}$ for 16 hours [32]. The tryptic peptides were extracted with ACN containing $0.1 \%$ formic acid (FA), dried using vacuum, and dissolved in $0.1 \%$ FA. The peptides were delivered onto a nano RP column (5$\mu \mathrm{m}$ Hypersil C18, $75 \mathrm{~mm} \times 100 \mathrm{~mm}$; Thermo Fisher Scientific, Waltham, MA, USA) and eluted with increasing concentrations (50-80\%) of ACN for 60 $\min$ at $400 \mathrm{~nL} / \mathrm{min}$. Different fractions of the eluate were injected into a Q-Exactive mass spectrometry (Thermo Fisher Scientific, Waltham, MA, USA) set in a positive ion mode and a data-dependent manner with a full MS scan from 350 to 2,000 m/z. High collision energy dissociation was used as the MS/MS acquisition method. Raw MS/MS data were converted to an MGF format with Proteome Discoverer 1.2 (Thermo Fisher Scientific, Waltham, MA, USA). The exported MGF files were searched with Mascot v2.3.01 in local server against the human SwissProt_new xyzzy database (20255 sequences). All searches were carried out with a tryptic specificity allowing one missed cleavage. Carbamidomethylation was regarded as a fixed modification whereas oxidation (M) and Gln->pyroGlu (N-term Q) as variable modifications. The mass tolerance for MS and MS/MS was $15 \mathrm{ppm}$ and $20 \mathrm{mmu}$, respectively. Proteins with false discovery rates $<0.01$ were further analyzed.

\section{Statistical analyses}

The methods used for statistical comparisons were indicated in the relevant tables, with $\mathrm{p}<0.05$ considered statistically significant.

\section{CONCLUSIONS}

In conclusion, only $34.4 \%, 35.9 \%$ and $22.2 \%$ LCMS/MS-identified proteins from MB231 cells and 24.9\%, $34.6 \%$ and $26.5 \%$ proteins from MCF7 cells from the $48 \mathrm{kD}, 55 \mathrm{kD}$ and $72 \mathrm{kD}$ stripes, respectively, belong to the WT category, with the remaining preponderance having a TMM larger or smaller than the WT range. About 24.6\% and $22.7 \%$ of the proteins identified by LC-MS/MS from MCF7 and MB231 cells, respectively, or on average 23.7\%, appeared in all three stripes, indicating that about one-fourth of the proteins may have multiple isoforms. About 3-16\%, on average about $10 \%$ regardless of the stripes and cell lines, of the proteins appear solely in one stripe and within the WT range. Considering that we have only studied three stripes and those "solely in one stripe" may also appear in another unstudied position of the SDS-PAGE, probably few genes in the human genome produce only the WT protein without at least one additional isoform. This astonishing conclusion questions some common practices in biomedical research, including WB and immunohistochemical staining.

\section{Abbreviations}

AA, amino acid; ACN, acetonitrile; ACTP, approximate coverage of truncated proteins; $\mathrm{CR}$, coverage rate; FA, formic acid; PLEC, plectin-isoform-1 gene; SDSPAGE, sodium dodecyl sulfate-containing polyacrylamide gel; kD, kilo-Dalton; LC-MS/MS, liquid chromatography together with tandem mass spectrometry; WT, wild type; WB, western blotting; TMM, theoretical molecular mass.

\section{Author contributions}

RY: analyzing data, preparing figures and drafting manuscript. JZ and LZ: analyzing data and preparing figures. DW: analyzing some data. SL and NX: formulating the concepts and ideas and correcting the manuscript. DJL: preparing and finalizing the manuscript.

\section{ACKNOWLEDGMENTS}

We would like to thank Dr. Fred Bogott at Austin Medical Center, Austin of Minnesota, for his excellent English editing of this manuscript.

\section{CONFLICTS OF INTEREST}

None of the authors have interest conflicts to declare.

\section{FUNDING}

This work was supported by a grant from Chinese Natural Science Foundation to Joshua D. Liao (grant No. 81660501). 


\section{REFERENCES}

1. Kornblihtt AR, Schor IE, Allo M, Dujardin G, Petrillo E, Munoz MJ. Alternative splicing: a pivotal step between eukaryotic transcription and translation. Nat Rev Mol Cell Biol. 2013; 14:153-65

2. Jia Y, Chen L, Ma Y, Zhang J, Xu N, Liao DJ. To know how a gene works, we need to redefine it first but then, more importantly, to let the cell itself decide how to transcribe and process its RNAs. Int J Biol Sci. 2015; 11:1413-23.

3. Gorr TA, Vogel J. Western blotting revisited: critical perusal of underappreciated technical issues. Proteomics Clin Appl. 2015; 9:396-405.

4. Liu X, Wang Y, Yang W, Guan Z, Yu W, Liao DJ. Protein multiplicity can lead to misconduct in western blotting and misinterpretation of immunohistochemical staining results, creating much conflicting data. Prog Histochem Cytochem. 2016; 51:51-8.

5. Ahmad Y, Boisvert FM, Lundberg E, Uhlen M, Lamond AI. Systematic analysis of protein pools, isoforms, and modifications affecting turnover and subcellular localization. Mol Cell Proteomics. 2012; 11:M111.013680. https://doi.org/10.1074/mcp.M111.013680.

6. Ezkurdia I, Vazquez J, Valencia A, Tress M. Analyzing the first drafts of the human proteome. J Proteome Res. 2014; 13:3854-5.

7. Kim MS, Pinto SM, Getnet D, Nirujogi RS, Manda SS, Chaerkady R, Madugundu AK, Kelkar DS, Isserlin R, Jain S, Thomas JK, Muthusamy B, Leal-Rojas P, et al. A draft map of the human proteome. Nature. 2014; 509:575-81.

8. Wilhelm M, Schlegl J, Hahne H, Moghaddas GA, Lieberenz M, Savitski MM, Ziegler E, Butzmann L, Gessulat S, Marx H, Mathieson T, Lemeer S, Schnatbaum K, et al. Massspectrometry-based draft of the human proteome. Nature. 2014; 509:582-7.

9. Ezkurdia I, Juan D, Rodriguez JM, Frankish A, Diekhans M, Harrow J, Vazquez J, Valencia A, Tress ML. Multiple evidence strands suggest that there may be as few as 19,000 human protein-coding genes. Hum Mol Genet. 2014; 23:5866-78.

10. Ezkurdia I, Calvo E, Del PA, Vazquez J, Valencia A, Tress ML. The potential clinical impact of the release of two drafts of the human proteome. Expert Rev Proteomics. 2015; 12:579-93.

11. Toby TK, Fornelli L, Kelleher NL. Progress in top-down proteomics and the analysis of proteoforms. Annu Rev Anal Chem (Palo Alto Calif). 2016; 9:499-519.

12. Zhang J, Lou X, Shen H, Zellmer L, Sun Y, Liu S, Xu N, Liao DJ. Isoforms of wild type proteins often appear as low molecular weight bands on SDS-PAGE. Biotechnol J. 2014; 9:1044-54.

13. Reddy PJ, Ray S, Srivastava S. The quest of the human proteome and the missing proteins: digging deeper. OMICS. 2015; 19:276-82.
14. Yagoub D, Tay AP, Chen Z, Hamey JJ, Cai C, Chia SZ, Hart-Smith G, Wilkins MR. Proteogenomic discovery of a small, novel protein in yeast reveals a strategy for the detection of unannotated short open reading frames. J Proteome Res. 2015; 14:5038-47.

15. Olexiouk V, Crappe J, Verbruggen S, Verhegen K, Martens L, Menschaert G. sORFs.org: a repository of small ORFs identified by ribosome profiling. Nucleic Acids Res. 2016; 44:D324-D329.

16. Nelson BR, Makarewich CA, Anderson DM, Winders BR, Troupes CD, Wu F, Reese AL, McAnally JR, Chen X, Kavalali ET, Cannon SC, Houser SR, Bassel-Duby R, Olson EN. A peptide encoded by a transcript annotated as long noncoding RNA enhances SERCA activity in muscle. Science. 2016; 351:271-5.

17. Hertweck C. Biosynthesis and charging of pyrrolysine, the 22nd genetically encoded amino acid. Angew Chem Int Ed Engl. 2011; 50:9540-1.

18. Peng Z, Yuan C, Zellmer L, Liu S, Xu N, Liao DJ. Hypothesis: artifacts, including spurious chimeric RNAs with a short homologous sequence, caused by consecutive reverse transcriptions and endogenous random primers. $\mathrm{J}$ Cancer. 2015; 6:555-67.

19. Yuan C, Han Y, Zellmer L, Yang W, Guan Z, Yu W, Huang $\mathrm{H}$, Liao DJ. It is imperative to establish a pellucid definition of chimeric RNA and to clear up a lot of confusion in the relevant research. Int J Mol Sci. 2017; 18. https://doi. org/10.3390/ijms18040714.

20. Mohler K, Aerni HR, Gassaway B, Ling J, Ibba M, Rinehart J. MS-READ: quantitative measurement of amino acid incorporation. Biochim Biophys Acta. 2017. https://doi. org/10.1016/j.bbagen.2017.01.025.

21. Huang P, Chen C, Liu-Chen LY. Detection of mu opioid receptor (MOPR) and its glycosylation in rat and mouse brains by western blot with anti-muC, an affinity-purified polyclonal anti-MOPR antibody. Methods Mol Biol. 2015; 1230:141-54.

22. Ezkurdia I, Rodriguez JM, Carrillo-de Santa PE, Vazquez J, Valencia A, Tress ML. Most highly expressed proteincoding genes have a single dominant isoform. J Proteome Res. 2015; 14:1880-7.

23. Tucher J, Koudelka T, Schlenk J, Tholey A. From top-down to bottom-up: time-dependent monitoring of proteolytic protein degradation by LC-MS. J Chromatogr B Analyt Technol Biomed Life Sci. 2016; 1015-1016:111-20.

24. Sarsby J, Martin NJ, Lalor PF, Bunch J, Cooper HJ. Topdown and bottom-up identification of proteins by liquid extraction surface analysis mass spectrometry of healthy and diseased human liver tissue. J Am Soc Mass Spectrom. 2014; 25:1953-61.

25. You Z, Dong Y, Kong X, Zhang Y, Vessella RL, Melamed J. Differential expression of IL-17RC isoforms in androgendependent and androgen-independent prostate cancers. Neoplasia. 2007; 9:464-70. 
26. Sun Y, Cao S, Yang M, Wu S, Wang Z, Lin X, Song X, Liao DJ. Basic anatomy and tumor biology of the RPS6KA6 gene that encodes the p90 ribosomal S6 kinase-4. Oncogene. 2013; 32:1794-810.

27. Sun Y, Lou X, Yang M, Yuan C, Ma L, Xie BK, Wu JM, Yang W, Shen SX, Xu N, Liao DJ. Cyclin-dependent kinase 4 may be expressed as multiple proteins and have functions that are independent of binding to CCND and RB and occur at the $\mathrm{S}$ and $\mathrm{G} 2 / \mathrm{M}$ phases of the cell cycle. Cell Cycle. 2013; 12:3512-25.

28. Yang M, Sun Y, Ma L, Wang C, Wu JM, Bi A, Liao DJ. Complex alternative splicing of the smarca2 gene suggests the importance of smarca2-B variants. J Cancer. 2011; 2:386-400.

29. Yang M, Wu J, Wu SH, Bi AD, Liao DJ. Splicing of mouse p53 pre-mRNA does not always follow the "first come, first served" principle and may be influenced by cisplatin treatment and serum starvation. Mol Biol Rep. 2012; 39:9247-56.

30. Karakas C, Biernacka A, Bui T, Sahin AA, Yi M, Akli S, Schafer J, Alexander A, Adjapong O, Hunt KK, Keyomarsi K. Cytoplasmic cyclin E and phospho-cyclin-dependent kinase 2 are biomarkers of aggressive breast cancer. Am J Pathol. 2016; 186:1900-12.

31. Marcel V, Khoury MP, Fernandes K, Diot A, Lane DP, Bourdon JC. Detecting p53 isoforms at protein level. Methods Mol Biol. 2013; 962:15-29.

32. Meng B, Qian Z, Wei F, Wang W, Zhou C, Wang Z, Wang Q, Tong W, Wang Q, Ma Y, Xu N, Liu S. Proteomic analysis on the temperature-dependent complexes in Thermoanaerobacter tengcongensis. Proteomics. 2009; 9:3189-200. 